\title{
Protocol for acclimatization of in vitro cultured Potamogeton praelongus - aspect of plantlet size and type of substrate
}

\author{
Romana Prausová1, Zuzana Kozelková1*, Lenka Šafářová \\ 'Department of Biology, Faculty of Science, University of Hradec Králové, 50002 Hradec Králové, Czech Republic \\ ${ }^{2}$ East Bohemian Museum in Pardubice, Zámek 2, 53002 Pardubice, Czech Republic
}

\begin{abstract}
The aim of the experiment was to determine suitable substrate type and optimal plant size for transfer of plantlets from in vitro to ex vitro under experimental outdoor conditions. Tests focused on the effect of substrate type (muddy and sandy) and starting size of plantlets gained through in vitro seed germination $(0-3,3.1-5,5.1-6,6.1-10 \mathrm{~cm}$ ) on plant growth. Three parameters (fresh weight, length, and the number of leaves) were compared to evaluate growth. Basic water parameters in experimental water tanks were regularly measured $(\mathrm{pH}$, temperature, electrical conductivity, shadow intensity) and controlled to reach similar conditions to those in the natural habitat of this species. Overwintering was studied in a cellar with newly defined size categories $(\leq 6,6.1-8,8.1-10,10.1-12,12.1-15 \mathrm{~cm})$.

Both substrate type and starting size of plantlets significantly impacted growth. Plantlets grew better in the muddy substrate while a $100 \%$ success rate of rooting was gained with a starting size of $6.1-10 \mathrm{~cm}$ in both substrates. The biggest increase in fresh weight was observed with a starting size of $3.1-5 \mathrm{~cm}$ and $5.1-6 \mathrm{~cm}$ in both substrates. The greatest increase in fresh weight was observed in plants with a starting size of $3.1-5 \mathrm{~cm}$ in the muddy substrate (more than $95 \%$ increase). The best overwintering results were gained in the $6.1-8 \mathrm{~cm}$ size category.
\end{abstract}

Keywords: Potamogeton praelongus; plant tissue culture; growth experiment

\section{Introduction}

Potamogeton praelongus is a rare plant all over the world, being found in northern, mildly suboceanic and circumpolar regions. It grows primarily in the northern part of Europe and in similar latitudes in Asia and North America [1] in running waters, lakes and water pools. It occurs predominantly in clear, still, up to moderately flowing water, preferably mezotrophic, with a muddy or clay-sandy bed, often also with a layer of sapropel or an admixture of gravel or stones [2].

In the Czech Republic, it is considered critically endangered and currently is only found in two rather poor micropopulations in oxbows of the Orlice River near Hradec Králové [2], where it grows in a layer of organic mud [3]. Only one of these micropopulations is native - in the temporarily protected area (TPA) "Rameno u Stř́ibrného rybníku". In the past, $P$. praelongus was abundant in the $\mathrm{CR}$ from lowlands to highlands.

\footnotetext{
* Corresponding author. Email: zuzana.kozelkova@uhk.cz
}

Handling Editor: Beata Zagórska-Marek
The last native Czech micropopulation of $P$. praelongus (in TPA) is endangered by deposition of nutrient-rich sediment which covers the leaf surfaces with fine particles $[4,5]$ and causes growth of metaphytic filamentous green algae. Disturbance of plants and micropopulations due to flood events is also of potential concern.

Genetic analyses detected a low level of intra- and interpopulation genetic diversity in the Czech micropopulations [6] due to clonal growth, as known with other aquatic plant populations [7]. In nature, the achenes of $P$. praelongus are probably only used for colonization of new sites [8]. Present results indicate that the genetic variability of the micropopulations can be considerably increased by sexual reproduction in rescue cultures. Experimental studies reported a rapid spread of immigrant genomes within inbred populations due to heterosis [9-11]. Small amounts of artificial genes that have flowed into natural populations quickly reduced inbreeding depression and fitness reductions from a fixed genetic load [12-14].

Potamogeton praelongus prefers vegetative to generative reproduction in its whole range [2]. Germination tests were conducted during 2007-2013 to determine how to use the generative reproductive ability of the plant, which is strongly restricted by dormancy $[8,15]$. A $P$. praelongus tissue culture 
was set up in Ostrava (Czech Republic) and 30 clones are maintained there at present. Plantlets from this tissue culture were provided to the University of Hradec Králové for this experiment.

Since 2003, the Czech Republic has been running a conservation programme aimed at preserving $P$. praelongus through establishing new micropopulations in appropriate original locations of this species. Re-introductions of P. praelongus have only been successful twice although many potential original locations have been tried. The aim of this experiment was to determine how to increase the success rate of further re-introductions by choosing the appropriate substrate and determining the best plantlet starting size for acclimatization of the minute and vulnerable tissue cultured plantlets. These plantelets would then have to be grown until they reach a sufficient size and vitality for their successful plantation into suitable natural sites. Incorporating genetically variable material from 30 different clones should also help to improve the genetic variability.

\section{Material and methods}

\section{Material from plant tissue culture}

Seeds harvested in the rescue culture of $P$. praelongus at the Institute of Botany in Třeboň (Czech Republic) in September 2009 were used for preparation of a sterile in-vitro culture in Ostrava [5]. After two months of post-germination growth, seedlings were transplanted into a fresh liquid medium of a higher concentration (half strength Gamborg B5 medium with $500 \mathrm{mg} \mathrm{l}^{-1} \mathrm{KNO}_{3}$, with $2.5 \%$ sucrose, $\mathrm{pH}$ 5.7 or 6.5) [16]. The volume of renewed culture medium was $50-70 \mathrm{ml}$ in $350-\mathrm{ml}$ flasks or $300 \mathrm{ml}$ in $0.5-1$ flasks. Sterile plantlets were cultivated at $21^{\circ} \mathrm{C}$, with artificial lighting of 20-30 PAR coming from two linear fluorescent tubes for 12 hours a day. Cultivation was conducted without shaking [5].

Seedlings rapidly showed vigorous growth after transfer into the new medium. The plants outgrew the flasks after 2-3 months (about 8-15 shoot apices were produced) and exhausted the medium (its final $\mathrm{pH}$ was 4.65-6.25). At this point, 1-3 apical shoot segments were transplanted into new flasks [5] to remain in the rescue culture and the rest of the plants were provided to the University of Hradec Králové for a growth experiment.

\section{Starting the growth experiment}

The experiment was carried out in an experimental culture in Býšt in artificially established water tanks with site conditions comparable to those of the last habitat of this species in the CR. At the end of June 2012, 488 plantlets of 23 clones of $P$. praelongus from the plant tissue culture in Ostrava (Fig. 1) were sorted into four size categories (plant length $0-3,3.1-5,5.1-6,6.1-10 \mathrm{~cm}$ ). On 1.7.2012, these plantlets were planted into plastic containers of $0.25-0.751$ volume $(0.251$ for $0-3 \mathrm{~cm}$ plants, 0.31 for $3.1-5 \mathrm{~cm}$ plants, 0.51 for $5.1-6 \mathrm{~cm}$ plants, 0.751 for $6.1-10 \mathrm{~cm}$ plants) and placed into 3 parallel water tanks $(A, B, C)$ filled to the top edge with unchlorinated well water. The dimensions of the tanks were (length, width, depth): A: $0.70 \times 0.70 \times 0.28 \mathrm{~m}$ (135 l); B: $0.70 \times 0.70 \times 0.28 \mathrm{~m}(135 \mathrm{l})$; C: $1.00 \times 0.70 \times 0.26 \mathrm{~m}$
(175 1). The plants were grown in two types of substrate, muddy (245 plants) and sandy (243 plants). Plastic containers with either muddy or sandy substrate were put into each tank, e.g. water conditions were similar in all water tanks. Both substrates contained sand ( $\mathrm{pH}$ of the sand infusion in distilled water was 6.77) and were enriched with a small amount of clay ( $1 / 6$ of total volume), which acted as a source of $\mathrm{Ca}^{2+}$ ions thus influencing the final $\mathrm{pH}$ of the substrate and water. The mud added into the muddy substrate consisted of undecomposed black organic material with a $\mathrm{pH}$ of 7.4, and nutrient contents of $\mathrm{NH}_{4}{ }^{+}: 23 \mathrm{mg} \mathrm{kg}^{-1}, \mathrm{NO}_{3}^{-}: 30 \mathrm{mg} \mathrm{kg}^{-1}$, $\mathrm{P}_{\text {total }}: 420 \mathrm{mg} \mathrm{kg}^{-1}$. The proportion of mud and sand in the muddy substrate was $1: 1$. Both the mud and the sand were taken from the standing oxbow in the TPA (mud from its filled parts, sand from the sandy alluvium below the mouth of Strŕbrný stream into the oxbow).

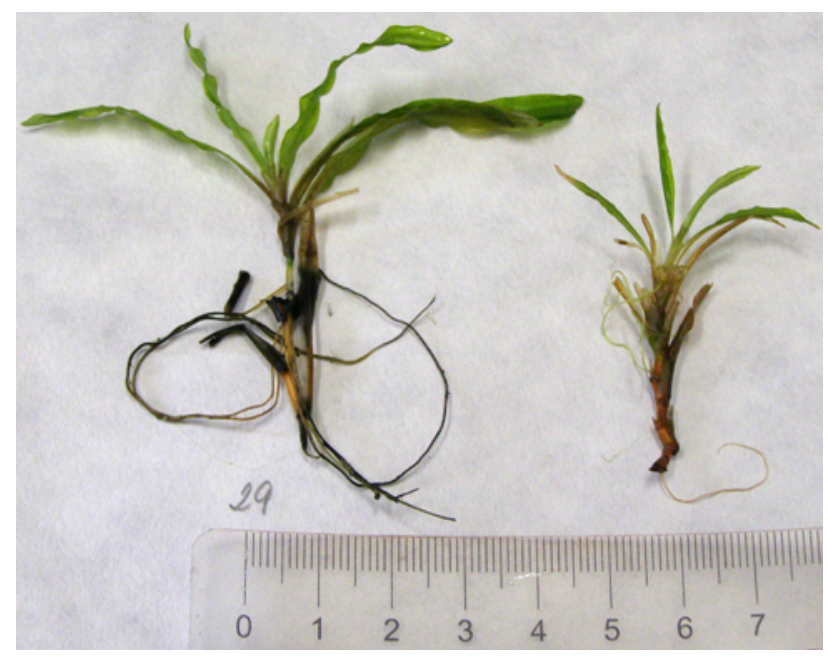

Fig. 1 Plantlets from sterile plant tissue culture (clone No. 29), scale in $\mathrm{cm}$.

The starting length and fresh weight of every plantlet were determined (Tab. 1). The fresh weight was measured immediately after blotting the plantlets with filter paper, using laboratory scales with an accuracy of $0.0001 \mathrm{~g}$. Fresh weight instead of dry weight was used to assess growth in order not to destroy the plants.

Tab. 1 Survey of number of plants in each size category.

\begin{tabular}{lcccc}
\hline & \multicolumn{2}{c}{ Mud } & \multicolumn{2}{c}{ Sand } \\
\cline { 2 - 5 } $\begin{array}{l}\text { Plant length } \\
(\mathbf{c m})\end{array}$ & $\begin{array}{c}\text { Number of } \\
\text { plants }\end{array}$ & $\begin{array}{c}\text { Mean } \\
\text { weight (g) }\end{array}$ & $\begin{array}{c}\text { Number of } \\
\text { plants }\end{array}$ & $\begin{array}{c}\text { Mean } \\
\text { weight }(\mathrm{g})\end{array}$ \\
\hline $0-3$ & 118 & 0.0677 & 117 & 0.0720 \\
$3.1-5$ & 80 & 0.1737 & 79 & 0.1897 \\
$5.1-6$ & 27 & 0.2599 & 27 & 0.2245 \\
$6.1-10$ & 10 & 0.3663 & 10 & 0.3319 \\
Total & 245 & 0.2169 & 243 & 0.2045 \\
\hline
\end{tabular}




\section{End of experiment}

The growth experiment finished on 24.10.2012. The plants were carefully washed with tap water and the final fresh weight, plant length and number of leaves on the stalk were determined immediately after blotting the fresh plants with filter paper (Fig. 2). All plants from this growth experiment were placed into a cellar for overwintering from November to May. Water temperature in the overwintering water tank did not drop below $0^{\circ} \mathrm{C}$. Every weekend, the water was continuously aerated with an aerator device. Newly defined size categories $(\leq 6,6.1-8,8.1-10,10.1-12,12.1-15 \mathrm{~cm})$ were used for studying overwintering success.

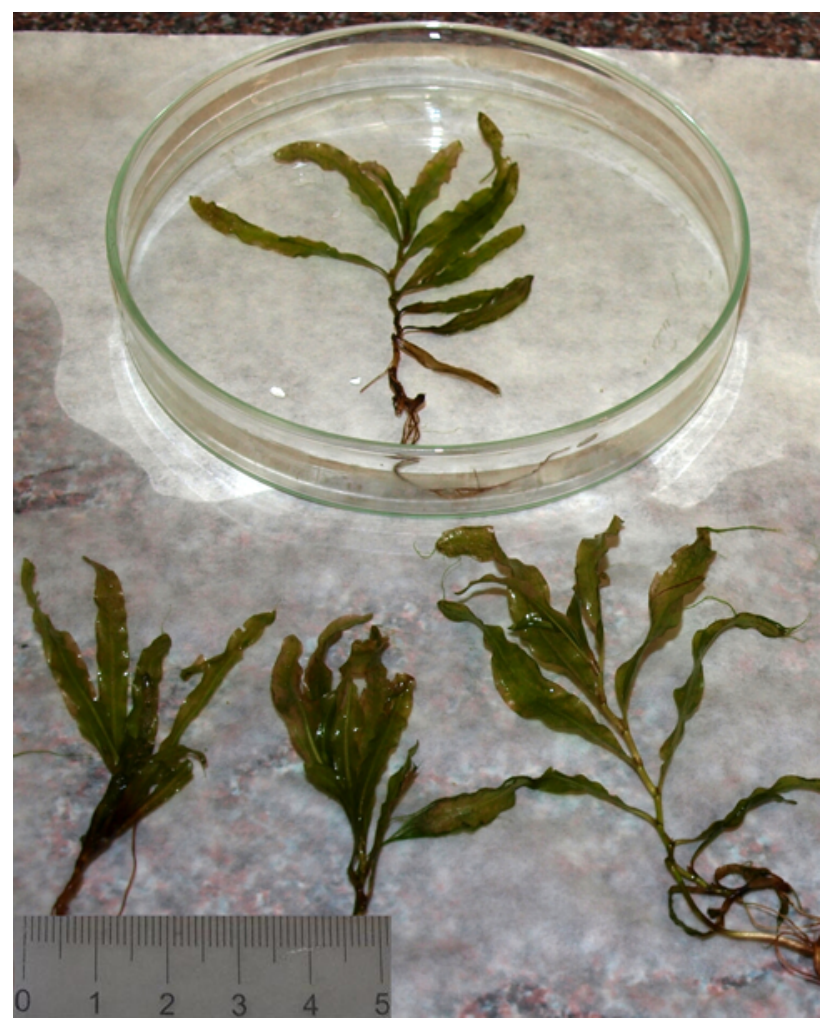

Fig. 2 Plants at the end of the growth experiment (before measurement), scale in $\mathrm{cm}$.

\section{Continuous measurement of parameters of the experiment}

Basic water parameters ( $\mathrm{pH}$, temperature, electrical conductivity, and shadow intensity) were regularly measured in the water tanks. Electrical conductivity and $\mathrm{pH}$ were measured by a Gryf 107 L portable combined device. Air and water temperatures were measured by a Multi-Thermo portable thermometer with range from $-50^{\circ} \mathrm{C}$ to $300^{\circ} \mathrm{C}$. Light conditions in particular water tanks were measured using a Voltcraft LX-1108 digital photometer. Shadow intensity was calculated as the ratio of actual lighting of the water tank and lighting of an unshaded space, and expressed in percentage of shading. Long-term monitoring of the temperature course was made with a Minikin data logger (Environmental Measuring Systems, Brno) placed in water tank $\mathrm{C}$ (representative tank) and in the water tank with overwintering plants. Chemical analyses of samples of surface water and muddy substrate were carried out to compare the conditions in the experimental culture in Býšt and in the native locality of $P$. praelongus in TPA; the analyses were conducted by the water management laboratories in the state enterprise of Povodí Labe, s.p.

Furthermore, a parallel all-day measurement of water temperature, shadow intensity, $\mathrm{pH}$, and electrical conductivity was carried out with portable devices in both localities on 26.7.2012 (Fig. 3) so to compare the conditions in the representative water tank and TPA.

a
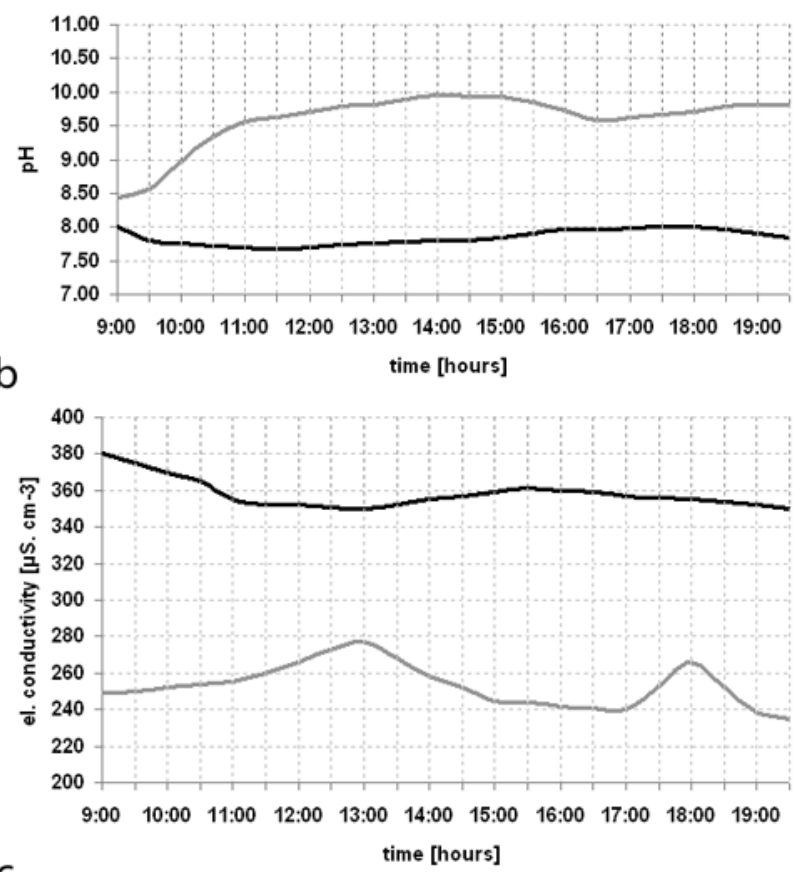

C

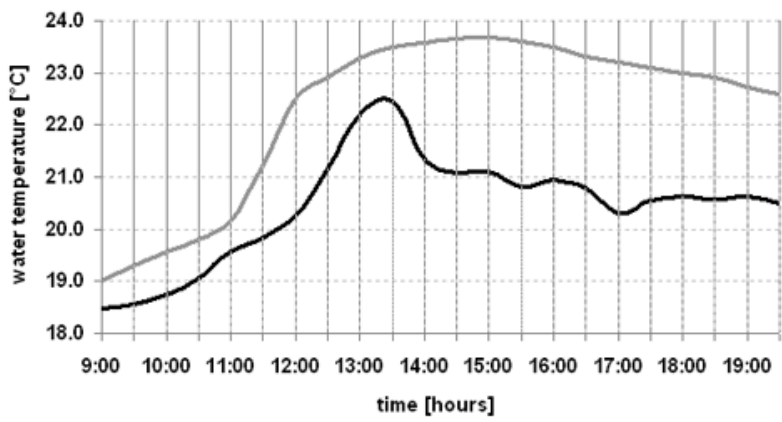

d

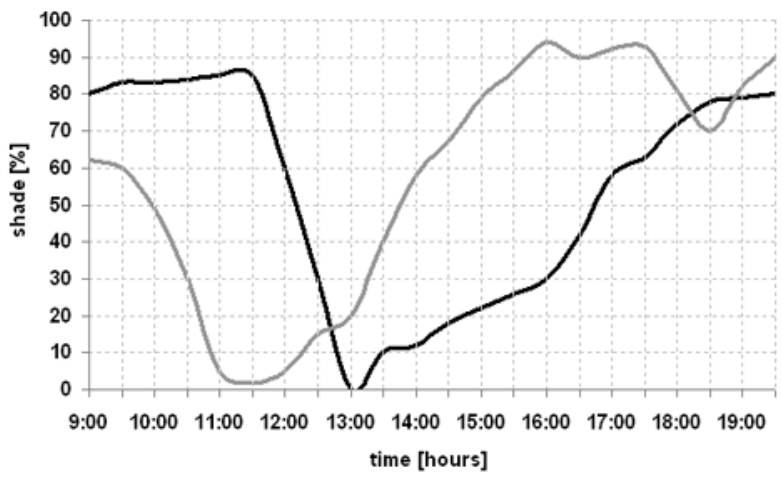

Fig. 3 All-day measurement of $\mathrm{pH}$, water temperature, light conditions (shade) and electrical conductivity in TPA (black) and the experimental culture (grey). 


\section{Statistical evaluation}

All statistical analyses were performed using NCSS 2001 [17]. The size categories of 5-6 and 6-10 cm had to be combined $(5-10 \mathrm{~cm})$, because of the small number of plants in each of these categories. The effect of the substrate type (mud and sand) on plant survival was evaluated by a Chi-Squared test. $T$-tests were run to test the effect of the substrate type (mud and sand) on the final fresh weight in particular size categories. The non-parametric Kruskal-Wallis test was used to compare the final fresh weight and number of leaves in the mud and sand substrates.

\section{Results}

$\mathrm{pH}$ values were higher than 8 in the water tanks, surpassing the values measured in TPA by 1-2 degrees (Fig. 3a). In both the experimental culture and TPA, precipitated $\mathrm{CaCO}_{3}$ created white, rough layers on the leaf surface. The electrical conductivity in the tanks with the experimental culture was lower (23-27 $\mathrm{mS} \mathrm{m}^{-1}$ ) than in TPA (35-37 $\mathrm{mS} \mathrm{m}^{-1}$; Fig. 3b). Temperature in the water tanks was comparable to that in TPA, being higher by $2^{\circ} \mathrm{C}$ at most than in the original locality during only a short period of the day (Fig. 3c). Also the shadow intensity in the experimental culture and TPA were similar (Fig. 3d).

One-time samples of water from TPA and the experimental culture showed differences in $\mathrm{COD}_{\mathrm{Mn}}, \mathrm{NO}_{2}, \mathrm{NH}_{4}$, $\mathrm{NO}_{3}, \mathrm{~N}_{\text {total }}, \mathrm{PO}_{4}, \mathrm{Ca}$, and $\mathrm{Mg}$ contents (Tab. 2). Although the soil substrates used in the experimental culture came from TPA, their chemical properties were different when used in the water tanks.

Substrate type in the experimental culture significantly affected the growth and number of surviving plants originating from a plant tissue culture. On the whole, 318 of 488 plants survived till the end of the experiment. The survival rate was higher in the muddy substrate (188 plants, $36.89 \%$ ) than in the sandy one (130 plants, $26.64 \%$; Tab. 3 ).

The survival rate was lowest in the $3.1-5 \mathrm{~cm}$ size category in both types of substrate. A $100 \%$ success rate of rooting was observed in the $6.1-10 \mathrm{~cm}$ size category in both types of substrate. The substrate type significantly impacted the number of surviving plants in the $3.1-5 \mathrm{~cm}$ and $5.1-10 \mathrm{~cm}$ size categories (Tab. 4).

The final fresh weight was higher in plants grown in the muddy substrate. The impact of substrate type on the fresh weight of the surviving plants was statistically significant in all size categories $(0-3,3-5,5-10 \mathrm{~cm}$; Tab. 4, Fig. 4).

The starting size of the tissue-cultured plantlets also significantly impacted the growth and fresh weight production of the plants (Tab. 5, Fig. 5). Plants grown in the muddy substrate had greater increases in fresh weight than those growing in the sand in all size categories. The best results were reached in the size category $0-3 \mathrm{~cm}$ where the fresh weight increased $14.5 \times$ in the mud and $5 \times$ in the sand. The second highest increase of fresh weight was observed with plants in the $3.1-5 \mathrm{~cm}$ size category in mud $(11.7 \times)$ while the lowest increase $(1.7 \times)$ was found in the sand. Fresh weight increased $5.5 \times$ in the mud and $2.4 \times$ in the sand in the $5.1-10 \mathrm{~cm}$ size category.
Tab. 2 Comparison of water parameters in the experimental culture and in TPA (sampling June 2013).

\begin{tabular}{lccc}
$\begin{array}{l}\text { Water } \\
\text { parameters }\end{array}$ & Unit & $\begin{array}{c}\text { Experimental } \\
\text { culture in Býśt }\end{array}$ & TPA \\
\hline el. conductivity & $\mathrm{mS} \mathrm{m}^{-1}$ & 23.4 & 32.3 \\
$\mathrm{pH}$ & & 9.8 & 7.6 \\
$\mathrm{COD}_{\mathrm{Mn}}$ & $\mathrm{mg} \mathrm{l}^{-1}$ & 17 & 16.80 \\
$\mathrm{NO}_{2}$ & $\mathrm{mg} \mathrm{l}^{-1}$ & 0.013 & 0.072 \\
$\mathrm{NH}_{4}$ & $\mathrm{mg} \mathrm{l}^{-1}$ & 0.06 & 0.04 \\
$\mathrm{NO}_{3}$ & $\mathrm{mg} \mathrm{l}^{-1}$ & $<0.5$ & 10.2 \\
$\mathrm{~N}_{\text {total }}$ & $\mathrm{mg} \mathrm{l}^{-1}$ & 1.1 & 2.7 \\
$\mathrm{PO}_{4}$ & $\mathrm{mg} \mathrm{l}^{-1}$ & 0.33 & 0.16 \\
$\mathrm{Ca}$ & $\mathrm{mg} \mathrm{l}^{-1}$ & 28.7 & 49.7 \\
$\mathrm{Mg}$ & $\mathrm{mg} \mathrm{l}^{-1}$ & 4.2 & 5.5 \\
\hline
\end{tabular}

Tab. 3 Number of planted and successfully grown plants of P. praelongus, and survival rates in mud and sand.

\begin{tabular}{|c|c|c|c|}
\hline Plant length $(\mathrm{cm})$ & Situation & Mud & Sand \\
\hline \multirow[t]{3}{*}{$0-3$} & Planted & 118 & 117 \\
\hline & $\begin{array}{l}\text { Successfully } \\
\text { grown }\end{array}$ & 86 & 76 \\
\hline & Survival rate $(\%)$ & 72.9 & 64.9 \\
\hline \multirow[t]{3}{*}{$3.1-5$} & Planted & 80 & 79 \\
\hline & $\begin{array}{l}\text { Successfully } \\
\text { grown }\end{array}$ & 56 & 24 \\
\hline & Survival rate $(\%)$ & 70.0 & 30.4 \\
\hline \multirow[t]{3}{*}{$5.1-6$} & Planted & 37 & 37 \\
\hline & $\begin{array}{l}\text { Successfully } \\
\text { grown }\end{array}$ & 36 & 20 \\
\hline & Survival rate $(\%)$ & 97.3 & 54.05 \\
\hline \multirow[t]{3}{*}{$6.1-10$} & Planted & 10 & 10 \\
\hline & $\begin{array}{l}\text { Successfully } \\
\text { grown }\end{array}$ & 10 & 10 \\
\hline & Survival rate $(\%)$ & 100 & 100 \\
\hline \multicolumn{2}{|l|}{ Planted altogether } & 245 & 243 \\
\hline \multicolumn{2}{|c|}{ Successfully grown altogether } & 188 & 130 \\
\hline \multicolumn{2}{|c|}{ Total survival rate (\%) } & 76.7 & 53.5 \\
\hline
\end{tabular}

Tab. 4 Chi-Squared statistics: associations between the substrate type and plants' survival in particular size categories. Significant results $(P \leq 0.05)$ are in bold.

\begin{tabular}{lccc} 
Size category $(\mathbf{c m})$ & Test statistics & d.f. & $\boldsymbol{P}$ \\
\hline $0-3$ & 1.72 & 1 & 0.189 \\
$3.1-5$ & 24.96 & 1 & $<\mathbf{0 . 0 0 1}$ \\
$5.1-10$ & 17.59 & 1 & $<\mathbf{0 . 0 0 1}$ \\
\hline
\end{tabular}


The initial size category significantly affected the final number of leaves on the stalk (Tab. 5). The maximum number of leaves was reached by plants of starting size $3.1-5 \mathrm{~cm}$ in the mud (25 leaves), and with plants of starting size $0-3 \mathrm{~cm}$ in the sand (10 leaves; Fig. 6). In the $6.1-10 \mathrm{~cm}$ size category, the final number of leaves did not noticeably differ from the initial one. However, leaf surface visually increased in this category.
Tab. 5 Kruskal-Wallis test: associations between final fresh weight and number of leaves in the mud and sand substrates. Significant results $(P<0.05)$ are in bold.

\begin{tabular}{lccr} 
Size category $(\mathbf{c m})$ & Test statistics & d.f. & \multicolumn{1}{c}{$\boldsymbol{P}$} \\
\hline $0-3$ & 6.29 & 1 & $<\mathbf{0 . 0 0 1}$ \\
$3.1-5$ & 3.45 & 1 & $\mathbf{0 . 0 0 1}$ \\
$5.1-10$ & 2.31 & 1 & $\mathbf{0 . 0 2 4}$ \\
\hline
\end{tabular}

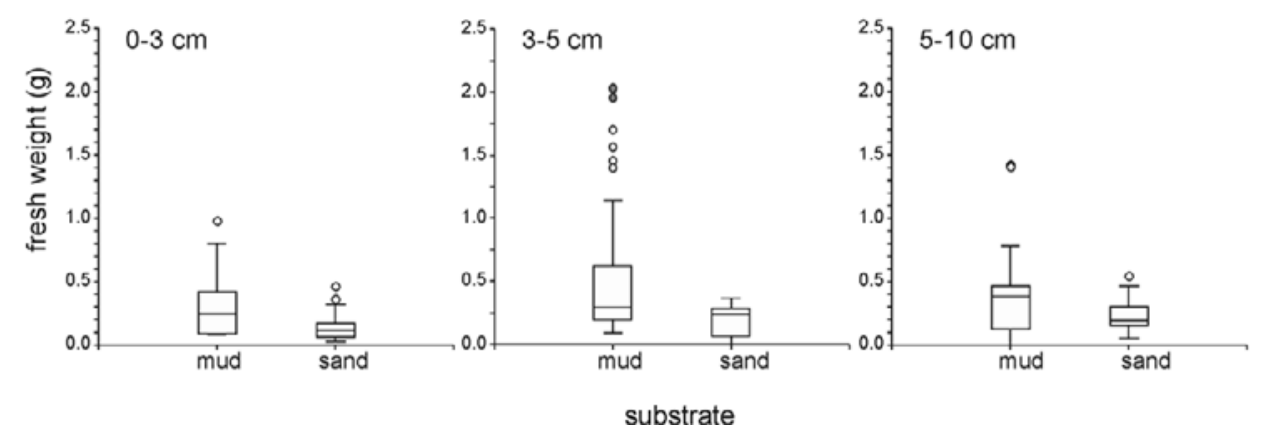

Fig. 4 Final fresh weight (g) of plants in the size categories $0-3,3.1-5$ and $5.1-10 \mathrm{~cm}$.

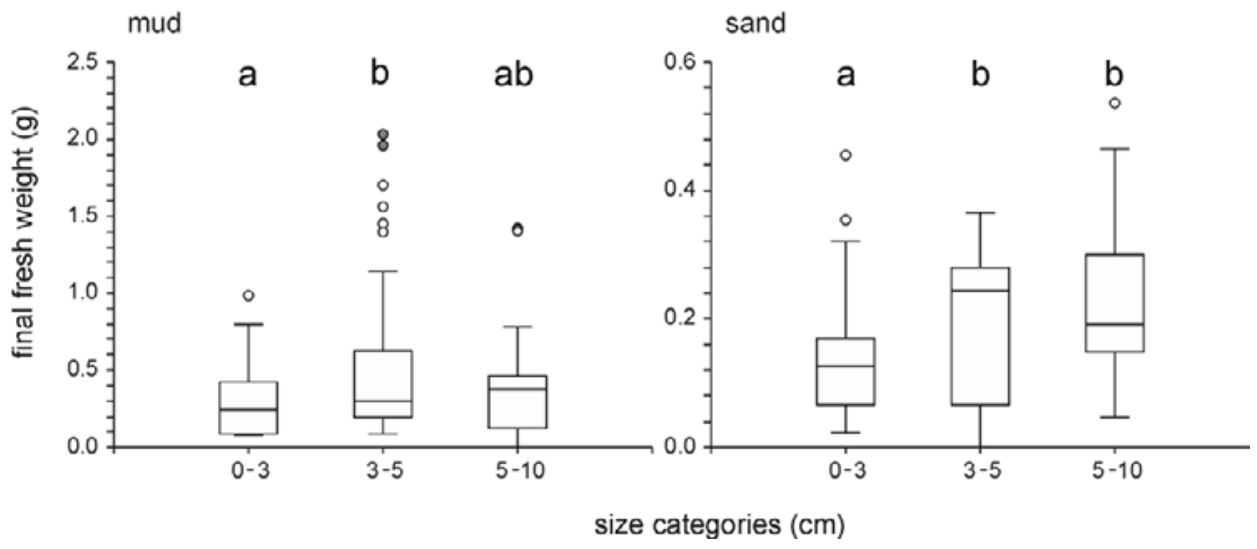

Fig. 5 Final fresh weight (g) of plants grown in the mud and sand substrates. Significant differences in medians (Dunn's test with $P=0.05$ ) between the size categories are marked by different letters above the diagrams.

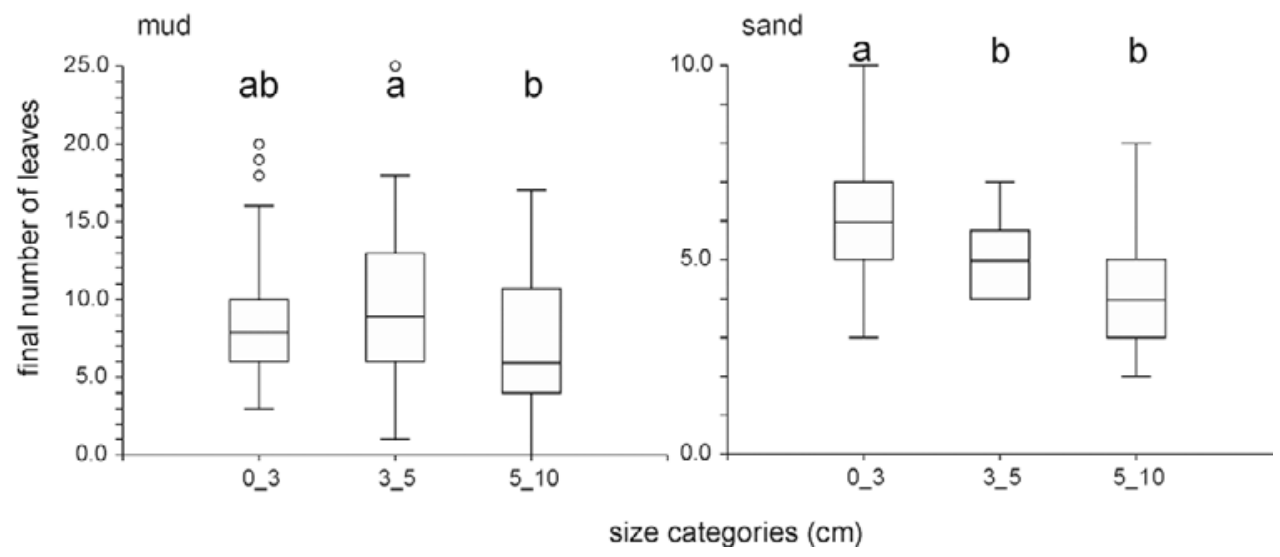

Fig. 6 Final leaf number on plants grown in the mud and sand substrates. Significant differences in medians (Dunn's test with $P=0.05$ ) between the size categories are marked by different letters above the diagrams. 
Tab. 6 Kruskal-Wallis test: associations between final fresh mass in the mud and in the sand. Significant results $(P \leq 0.05)$ are in bold.

\begin{tabular}{lccc} 
Substrate & Test statistics & d.f. & $\boldsymbol{P}$ \\
\hline mud & 7.09 & 2 & $\mathbf{0 . 0 2 9}$ \\
sand & 18.13 & 2 & $<\mathbf{0 . 0 0 1}$ \\
\hline
\end{tabular}

A total of $56.38 \%$ of plants successfully overwintered (Tab. 6), with the best results occurring in the $6.1-8 \mathrm{~cm}$ size category (100\%).

\section{Discussion}

Both substrates used in this growth experiment were taken from the last original locality of $P$. praelongus in CR, TPA “Rameno u Stříbrného rybníku”. The muddy black substrate with a high share of undecomposed organic material (fragments of leaves, branches, etc.) contains a high proportion of nitrogen in the forms $\mathrm{NO}_{3}{ }^{-}$and $\mathrm{NH}_{4}{ }^{+}$, phosphorus, and $\mathrm{Ca}^{2+}$ and $\mathrm{Mg}^{2+}$ cations. These nutrients have a positive effect on stalk growth, leaf formation, and underground organ formation. Plants grown in the sandy substrate were smaller, had less vitality, and lower survival rate. This confirms earlier results showing that $P$. praelongus has high demands for nutrients, which are mainly gained from the muddy sediment $[2,3]$. This species is found in relatively calcium rich water, on humic sandy soils and mud.

Potamogeton praelongus is very efficient photosynthetically and is able to efficiently use $\mathrm{HCO}_{3}{ }^{-}$ions as a source of carbon for photosynthesis, which gives it an advantage when growing in hard water [18-20].

Potamogeton praelongus is mostly found in weakly acidic up to weakly alkaline water with a moderate content of calcium [21-24] and in acidic to neutral substrates [25,26]. Research of the Czech localities showed that P. praelongus best thrives where $\mathrm{pH}$ values range from 7.1 to 8.4 , electrical conductivity is $11-41 \mathrm{mS} \mathrm{m}^{-1}$ and overall alkalinity is higher than $1.2 \mathrm{mekv}^{-1}$ [5]. Both the water $\mathrm{pH}$ and electrical conductivity values in the experimental culture were in the optimal ranges for the species. The content of nitrogenous materials in the experimental culture was lower than in TPA, because the water in the Orlice River is being constantly enriched with nitrogenous material washed off from the whole river basin. But the amount of $\mathrm{PO}_{4}{ }^{-}$was higher than in TPA, probably coming from the garden where the water tanks with $P$. praelongus were situated.

In CR, $P$. praelongus prefers water depth of $30-150 \mathrm{~cm}$ [2]. Outside the CR, it grows to a depth of several metres in lakes with high water transparency $[22,23,26,27]$. The species does not prosper in shallow and warmed water, where the stalks become brown and perish at the water surface in extremely hot temperatures. This was documented by observations of reserve micropopulations of this species in revitalized pools in the landscape park (LP) Kokořínsko [5]. Because the water tanks with the experimental culture in Býšt' were shallow, with depth under $0.3 \mathrm{~m}$, shadow intensity and water aeration were constantly controlled so that the plants were not overheated and damaged. Thus, the water temperature in the tanks was similar to that in TPA, although it was slightly higher during a short period of the day but by only $2^{\circ} \mathrm{C}$ at most. The shadow intensity in the experimental culture was managed to reach $0-80 \%$, which was in compliance with the natural conditions in TPA. $100 \%$ lighting of the water surface was limited to 1 hour per day at maximum in the water tanks as well as in TPA. Ellenberg [28] mentioned that $P$. praelongus is a light-demanding species only rarely growing in conditions with relative lighting under $40 \%$. However, in shallow waters in the CR, it prefers moderate shading by bank vegetation or floating plants that do not compete with it. $P$. praelongus was negatively affected by P. natans, Calliergonella cuspidata and Chara sp. in pools in LP Kokořínsko [5].

Unlike with previous plantings of $P$. praelongus, this method used 30 clones that were raised from seeds and thus should lead to increased genetic variability of the surviving Czech population. Kitner et al. [6] noticed that the current state of genetic variability of the Czech population of $P$. praelongus is alarming, because intrapopulation variability is higher than interpopulation variability. Within the scope of the rescue program for $P$. praelongus, the only successful attempts were repatriations into TPA, reintroduction into the Kašparovo oxbow in the flood plain of the Orlice River, and reintroduction into the Ploučnice River near Heřmaničky. These successful attempts used vital plants of about $0.5 \mathrm{~m}$ stalk size with well-developed rhizome systems from the rescue culture of the Institute of Botany of AS CR in Třebon̆, and the reserve populations in LP Kokořínsko. An important condition of rooting for the tissue-cultured plants in a natural environment is that they grow to a sufficient size and vitality before planting. Such important information was gained by this growth experiment, which showed the necessity of growing the tissue-cultured plantlets in a rich, alkaline substrate and in particular conditions (concerning the physical and chemical properties of the water and site). Also, this experiment confirmed that plant tissue culture is a good source of $P$. praelongus for subsequent repatriations and re-introductions. In this way, $P$. praelongus plants to be planted in an experimental culture reach a sufficient size in a much shorter time than through germination in the laboratory.

For planting, it is necessary that $P$. praelongus plants have 2-3 leaves. However, roots are formed mostly with plants that have 4-5 leaves. The presence and progressive extension of the root system is a helpful, but not necessary, condition for successful growth. Plant growth is noticeably accelerated after transfer into a soil substrate rich in nutrients. They then activate the growth of rootlets and rhizome. For planting into an experimental culture, plantlets of at least $3 \mathrm{~cm}$ length are sufficient, but for planting into a natural site, vital stalks of 20-30 cm (preferably with a rhizome) are necessary.

According to our experience with plantlets obtained from a tissue culture, sufficiently strong plants will be obtained in a rescue or experimental culture after 3 growing seasons, when the plants may start to be fertile. We are now testing plantlets from germination tests and suppose that their growth up to a sufficient size will take longer. It is important 
to successfully overwinter as many plants as possible. An outdoor deep water tank or a shallow water tank in a cellar, where the water temperature does not drop below $0^{\circ} \mathrm{C}$, can be used. Our overwintering experiment was carried out in a shallow water tank in a cellar with $56.38 \%$ survival.

Future growth experiments will focus on changes in underground organs during the growing and hibernal

\section{Acknowledgments}

The authors would like to thank M. Jůzová for translation into English and native speaker K. Edwards for English correction. The study was supported by funds awarded by EHP/Norway and the Ministry of Environment of the Czech Republic in 2009-2010, and by the funds of specific research financed by Ministry of Education of the Czech Republic in 2011-2012 No. 2121/2011, 2122/2012.

\section{Authors' contributions}

The following declarations about authors' contributions to the research have been made: research designing: RP; conducting experiments: RP, ZK; writing the manuscript: RP, ZK; statistical evaluation: L $\check{S}$.

\section{Competing interests}

No competing interests have been declared.

\section{References}

1. Vöge M. Die Entwicklung von Potamogeton praelongus im Großensee bei Hamburg. Tuexenia. 1992;12:275-284.

2. Kaplan Z. Potamogeton L. - rdest. In Chrtek J (jun.), Kaplan Z, Štěpánková J, editors. Květena České republiky. Prague: Academia; 2010. p. 330-378. (vol 8).

3. Šumberová K. Vegetace vodních rostlin zakořeněných ve dně (Potametea). In: Chytrý M, Šumberová K, Hájková P, Hájek M, Hroudová Z, Navrátilová J, et al., editors. Vegetace České republiky - vodní a mokřadní vegetace. Prague: Academia; 2011. p. 100-247. (vol 3).

4. Prausová R, Janová J. Současný stav výskytu rdestu dlouholistého (Potamogeton praelongus) v České republice. Př́roda. 2010;27:155-168.

5. Prausová R, Janová J, Adamec L. Rescue of the critically endangered long-stalked pondweed (Potamogeton praelongus) in the Czech Republic. Acta Biol Slov. 2011;54:43-54.

6. Kitner M, Prausová R, Adamec L. Present status of genetic diversity of Potamogeton praelongus populations in the Czech Republic. Phyton. 2013;53(1):73-86.

7. Waycott M. Assessment of genetic variation and clonality in the seagrass Posidonia australis using RAPD and allozyme analysis. Mar Ecol Prog Ser. 1995;116:289-295.

8. Prausová R, Janová J, Šafářová, L. Testing achene germination of Potamogeton praelongus Wulfen. Cent Eur J Biol. 2013;8(1):78-86. http://dx.doi.org/10.2478/s11535-012-0114-4

9. Ebert D, Haag C, Kirkpatrick M, Riek M, Hottinger JW, Pajunen VI. A selective advantage to immigrant genes in a Daphnia metapopulation. Science. 2002;295:485-488. http://dx.doi.org/10.1126/science.1067485

10. Richards CM. Inbreeding depression and genetic rescue in a plant metapopulation. Am Nat. 2000;155:383-394.

11. Saccheri IJ, Brakefield PM. Rapid spread of immigrant genomes into inbred populations. Proc R Soc Lond B. 2002;269:1073-1078. http:// dx.doi.org/10.1098/rspb.2002.1963

12. Madsen T, Shine R, Olsson M, Wittzell H. Conservation biology: restoration of an inbred adder population. Nature. 1999;402:34-35. http://dx.doi.org/10.1038/46941

13. Stokstad E. "Genetic rescue" helps panthers but puts researchers on the spot. Science. 2005;309:1162-1162. http://dx.doi.org/10.1126/ science.309.5738.1162 seasons. Current efforts in the frame of the rescue program for P. praelongus in the CR [29] aim to use the most recent findings about dormancy breaking in $P$. praelongus achenes [8] to gain genetically variable material for repatriations and re-introductions. The aim of this experiment was to find an alternative, possibly more efficient, method to rescue this critically endangered species in the CR and Central Europe.

14. Westemeier RL, Brawn JD, Simpson SA, Esker TL, Jansen RW, Walk JW, et al. Tracking the long-term decline and recovery of an isolated population. Science. 1998;282:1695-1698. http://dx.doi.org/10.1126/ science.282.5394.1695

15. Prausová R, Sikorová $P$, Šafářová $L$. Generative reproduction of long stalked pondweed (Potamogeton praelongus Wulfen) in the laboratory. Aquat Bot. 2014;120:268-274. http://dx.doi.org/10.1016/j. aquabot.2014.09.005

16. Adamec L, Pásek K. Medium optimization for growing Aldrovanda vesiculosa in vitro. Carniv Plant Newslett. 2000; 29:122-124.

17. Hintze, J. NCSS - Number Cruncher Statistical System. NCSS: Kaysville, UT; 2001.

18. Hough RA, Wetzel RG. Photosynthetic pathways of some aquatic plants. Aquat Bot. 1977;3:297-313. http://dx.doi. org/10.1016/0304-3770(77)90035-3

19. Husák Š, Kaplan Z. Studium a záchrana vybraných ohrožených druhů rodu Potamogeton. I. Potamogeton praelongus (Rameno u Stř́ibrného rybníka). Report for Agency for Nature Protection of the Czech Republic. Třeboň: Institute of Botany of the Academy of Science of the Czech Republic in Třeboň and Průhonice; 1997.

20. Maberly SC, Spence DHN. Photosynthetic inorganic carbon use by freshwater plants. J Ecol. 1983;71:705-724.

21. Berg C, Dengler J, Abdank A, Isermann M, editors. Die Pflanzengesellschaften Mecklenburg. Vorpommernsundihre Gefährdung - Textband. Jena: Weissdorn, Verlag; 2004.

22. Burnett JH, editor. The vegetation of Scotland. Edinburgh: Oliver \& Boyd; 1964 .

23. Doll R. Die Pflanzengesellschaften der stehender Gewässer in Mecklenburg - Vorpommern. Teil I. 3. Potamogetonetea Tx. et Prsg. 42. Laichkrautgesellschaften. Feddes Repert. 1991;102:217-317.

24. Nowak A, Nowak S. Czerniawska-Kusza I. Rare and threatened pondweed communities in anthropogenic waterbodies of Opole Silesia (SW Poland). Acta Soc Bot Pol. 2007;76(2):151-163. http:// dx.doi.org/10.5586/asbp.2007.019

25. Miljan A. Vegetations untersuchungen an Naturwiesen und Seen im Otepääschen Moränengebiet Estlands. Acta Commentat. 1933;25:1-139.

26. Vöge M. Ecological studies on water plants of 14 sites around Kangerlussuaq, southern West Greenland, with special regard to Potamogeton [Internet]. 2002 [cited 2014 Apr 23]. Available from: http://www. solo-tauchen.de/PDF/www04

27. Fajer M, Waga JM, Rzetala M, Szymczyk A, Nita M, Machowski R, et al. The Late Vistulian and Holocene evolution of Jezioro Lake: a record of environmental change in southern Poland found in deposits and landforms. J Paleolimnol. 2012;48:651-667. http://dx.doi.org/10.1007/ s10933-012-9634-1

28. Ellenberg H, Weber HE, Düll R, Wirth Y, Werner W, Paulißen D. Zeigerwerte der Gefässpflanzen Mitteleuropas. Scripta Geobot. 1991;18:1-248.

29. Prausová R, Rybka V, Adamec L, Husák Š, Rydlo J. Záchranný program pro rdest dlouholistý. Depon. In: Report for Ministry of Environment of CR. Pardubice: Agency for Nature Protection of the Czech Republic; 2003. 